\title{
感性品質における期待効果の要因モデル （予測の不確実性と事後に獲得する情報量が期待効果に与える影響）
} \author{
Factorial model of the expectation effect in perceived quality
(Effect of uncertainty and information gain on expectation effect) \\ Hideyoshi YANAGISAWA ${ }^{* 1}$, Kenji TAKATSUJI ${ }^{* 2}$ and Natsu MIKAMI ${ }^{* 2}$ \\ ${ }^{* 1,{ }^{* 2}}$ The University of Tokyo, School of Engineering \\ 7-3-1 Hongo, Bunkyo-ku, Tokyo 113-8656, Japan
}

柳澤 秀吉 ${ }^{* 1}$ ，高辻 賢司 ${ }^{* 2}$ ，三上 夏 ${ }^{* 2}$

Received 27 February 2014

\begin{abstract}
A user's experience of a product involves a set of transitions from one sensory state to another. For example, in the user's perception of a product's qualities, the state of their sensory modality may shift from vision to touch. Between such state transitions, users have expectations regarding their subsequent states based on their experience of a current state event. A disconfirmation between prior expectation and posterior experience evokes emotions such as surprise, satisfaction, and disappointment. Such emotions affect the user's perception of the value of a product. A noteworthy phenomenon in the perception of expectation disconfirmation is that the expectation affects the perceived experience itself. This psychological phenomenon called the expectation effect affects the user's perception of expectation disconfirmation. This effect is a key element for designing the affective experience of a product. Although experimental findings on the expectation effect exist in a variety of research disciplines, general and theoretical models of the effect have been largely neglected. In this paper, we propose a theoretical model of the expectation effect using information theory. We hypothesize that Shannon's entropy of the prior subjective probability distributions of posterior experience determines the occurrence of the expectation effect and that the amount of information gained after experiencing a posterior event is positively correlated with the intensity of the expectation effect. To verify these hypotheses, we conducted an experiment in which participants responded to the tactile qualities of surface texture. In the experiment, we extracted the visual expectation effect on tactile roughness during a sensory modality transition from vision to touch and analyzed the causes of the effect based on our hypotheses. The experimental results indicated the appropriateness of the proposed model of the expectation effect.
\end{abstract}

Key words : Design, Expectation effect, Information theory, Entropy, Crossmodality, Texture, Affective quality

\section{1. 緒言}

質感や使い心地など，ユーザーの感性にもとづいて評価される感性品質は，製品の魅力品質を高める重要な因 子である(Yanagisawa, 2010). ユーザーと製品の関わりの中で物理現象（たとえば，光，音，振動など）が生じ， これを刺激として，視覚，聴覚，触覚などの感覚を介して知覚した性質が感性品質である．物理現象またはその 要因となる製品の物理属性と，ユーザーの反応（たとえば，主観報告，行動，生理指標など）との関係を調べる ことで, 感性品質を代替する物理的な指標を導く(Yanagisawa, 2010)( Schütte, et al., 2004)(Mori, 2002). そして, そ の指標を設計の指針として利用寸る. 感性品質は, 音と聴覚, 色彩（光）と視覚の様に単一の感覚だけでなく, 複数の感覚を用いて知覚される場合が少なくない，たとえば，表面の質感は，視覚，触覚，および聴覚の複合と して知覚される質である，さらに，製品とユーザーとの関わりを時間軸で捉えると，利用する感覚を状況に応じ て切り替えて対象の感性品質を予測または体験する，たとえば，製品表面の質感においては，視覚によってその

No.14-00116 [DOI: 10.1299/transjsme.2014trans0284]

${ }^{* 1}$ 正員, 東京大学大学院工学系研究科（率113-8656 東京都文京区本郷 7-3-1）

*2 東京大学大学院工学系研究科

E-mail of corresponding author: hide@mech.t.u-tokyo.ac.jp 
触感を予測したあと，実際に対象に触れて触感を体験する場合が考えられる．この様に，利用する感覚を時間軸 における状態の変数としてとらえると，ユーザーと製品の関わりを感覚の状態遷移の連鎖として捉えることがで きる．各状態遷移においては，遷移前の予測と遷移後の経験を含む．この遷移において，予測と経験の間に不一 致を知覚した場合，ユーザーの注意を促し，その度合いによっては驚きの感情を引き起こす．また，その遷移が 快・不快の感情価を伴う場合, 満足や失望などの総合評価に影響する(Demir, et al., 2009) (Murakami, et al., 2011) (Oliver, 1977, 1980). Ludden らは，同一の見た目で材質が異なる複数種の製品プロトタイプを作成し，視覚と触 覚の不一致が製品に対する感情と好みに与える影響を調べている (Ludden, et al., 2012). 被験者実験の結果か ら，不一致によって生じる驚きが，興味，魅力などの正の感情と，混乱，苛立ちなどの負の感情を同時に喚起さ せ，それらの合成によって製品の好みに影響するとしている。 この様に, 状態遷移における予測と経験の不一致 （以下，期待不一致（expectation discrepancy）とよぶ）は，製品に対する感情や嗜好に影響する重要な因子であ る.

期待不一致の知覚において注目すべき現象として，事前の予測が事後の経験内容を変化させる期待効果 （expectation effect）がある．たとえば，筆者らの研究において，テクスチャ表面の触覚において，視覚による 予測が触覚による触感の知覚に影響する効果を確認している(柳澤, 高辻, 2012). 期待効果は, 予測と経験の差 を小さくする同化現象と, 差を大きくする対比現象がある. したがって, 期待不一致の知覚は, 予測の誤差と必 ずしも等価ではなく，期待効果の影響を受ける．期待効果は，感覚・知覚(柳澤，勇木，2012)(柳澤，高辻， 2012) ( Buckingham, et al., 2011) ( Deliza and MacFie, 1996) ( Flanagan and Beltzner, 2000), 報酬期待(Schultz, et al., 1997), 感情(Wilson et al., 1989)( Geers and Lassiter, 1999)など, さまざまな認知レベルで被験者実験による確認が なされている. 特に, 食品科学とマーケティング科学の分野における研究事例が多い. たとえば, パッケージに 起因する期待が飲料などの内容物の評価に与える影響が研究されている. 期待と実際との差異が大きくなるにつ れて，期待の影響が同化（assimilation）から対比（contrast）へと推移するモデルが提案されている(Schifferstein, 2001). しかしながら，期待効果が，なぜ，どの様に発生するのかのメカニズムにもとづく一般的な理論は見当 たらない. 期待効果を感性品質の設計に応用寸るためには，期待効果の発生とその強度の条件を一般的に解明す る必要があると考えた.

そこで, 本研究では, 情報理論を応用して期待効果の発生条件およびその強度を説明する数理モデルを提案す る. 提案モデルでは, 予測を主観確率分布としてとらえ, 主観確率分布から得られる情報エントロピーおよび情 報量を用いて, 期待効果の発生条件と強度を説明する. 視覚予測が触覚に与える期待効果を事例として, 被験者 実験から情報エントロピーと情報量を取得し，それらと期待効果との関係を分析することで提案モデルの妥当性 を議論する。

\section{2. 情報理論にもとづく期待効果の要因モデル}

\section{$2 \cdot 1$ 仮説}

事前から事後へ至る状態遷移において，事前の状態から事後に発生する事象を予測する場合を考える．このと き，遷移後に発生しうる事象は，ある確率分布にしたがって発生するとする．真の確率分布が分からない場合， 経験や知識に基づいて主観的に予測するとする，このとき，主観的に予測した場合の確率分布を主観確率分布

(subjective probability distributions) とよぶ.

主観確率分布がサイコロの様に一様分布に近い場合，主観的な予測が不確実な状態を意味する，逆に，特定の 事象に対する主観確率が高い場合，予測の不確実性が低い状態を表す，予測の不確実性は，トップダウン処理と しての予測とボトムアップ処理としての感覚入力の処理とのバランスを考える上で重要な指標となる(Strange, et al., 2005). 寸なわち, 予測の不確実性が高い場合は, 入力される感覚情報のみに頼らざるをえないためボトムア ップ処理が支配的となる．逆に，予測の不確実性が低い場合，トップダウン処理（予測）が経験内容に作用する と考えた. 言い換えれば, 期待効果は, トップダウン処理（予測）がボトムアップ処理（感覚入力）の知覚に与 える影響と捉えることができる. 確率分布の一様性は情報エントロピー（平均情報量）を用いて定量的にその度 合いを表すことができる(Shannon, et al., 1949). すなわち, 主観確率分布の情報エントロピーを予測の不確実性 
を表す指標として利用できる，そこで，主観確率分布の情報エントロピーが一定值以下の場合（すなわち，不確 実性が一定以下である程度予測できる場合）に期待効果が発生すると考えた.

ヒトの感覚運動制御（sensorimotor control）において，トップダウン処理とボトムアップ処理の協調により運 動の制御を実現していることが知られている，すなわち，ヒトの運動は，小脳におけるフィードフォワード制御

（トップダウン）と運動野におけるフィードバック制御（ボトムアップ）との協調からなる. 実際に，この制御 系をロボティクスに応用し, 迅速でなめらかな運動制御が実現されている(Kawato, 1996). Körding らは, 画面上 のテニスボールを打ち返す位置にカーソルを合わせるタスクを単純化した実験系を用いて, 感覚運動制御が予測 と感覚のベイズ統計的な統合により構成されていることを示した(Körding and Wolpert, 2004) . この実験では, テニスボールの位置を分布として学習させた後, 分布の期待值からずれた箇所にボールを放ち被験者のカーソル 運動を調べている. カーソルの位置情報に外乱を与えたところ, 学習された分布の期待值の方向にカーソル位置 が推移する傾向を示した．このことは，ボトムアップの不確実性の増加に伴い，トップダウン処理の影響が優位 となったことを示唆している. この議論は, 本研究における期待効果の発生条件に関する仮説と本質的に相似寸 る.ただし, 感覚運動系における議論が, 知覚系にそのまま適用できる保証はない. たとえば, 大きさ重さ錯覚 (size-weight illusion) を用いた研究では, 感覚運動系が重さに対して適切な把持力を学習した後も, 知覚系は学 習しない，すなわち錯覚が持続することが示されている(Flanagan and Beltzner, 2000). また，予測（トップダウ

ン）の不確実性が期待効果に与える影響をモデル化し実証した研究は見当たらない.

一方，事後の事象を経験することにより一定の情報量を得る．事後に獲得する情報量は，発生した事象に対す る事前の主観確率によって異なる. 寸なわち, 主観確率が低い（予測していなかった）事象の方が, 主観確率が 高い（予測していた）事象よりも多くの情報量をもたらす．主観確率の低い事象が生じ，多くの情報量を取得す ると「驚き (surprise)」が増し，感覚への注意を促す(Itti and Baldi, 2009). 感覚への注意は, 感覚入力に対する利 得を高める. そのため, 取得した情報量は期待効果の強度に影響すると考えた. 以上から, 本研究では以下の二 つの仮説を提案する.

仮説 1: 主観確率分布の情報エントロピーが一定值以下の時に期待効果が発生する.

仮説 2: 発生した事象の確率にもとづく情報量は，期待効果の強度と正の関係を持つ.

\section{$2 \cdot 2$ 期待不一致と期待効果の関係性}

人が製品を認識, 探究, 使用する過程は, 行為, 知覚, そして意味形成からなるサイクルから構成される (Krippendorff, 2005). たとえば, 製品に触れる行為によって表面の質感を知覚する. そして, 知覚の内容と過去 の経験や知識を照らし合わせ, 材質や高級感などの意味を形成する. 本論文では, 行為, 知覚, 意味のサイクル のまとまりを, 事象 (event) とよぶ. 今, 時間軸上で隣り合う状態間の遷移において, 遷移前の事象 $v$ と遷移 後の事象 $u$ を考える. 事象 $u$ によって経験しうる製品の感覚質の集合を $X$ と寸る. そして, 事象 $v$ から事象 $u$ による感覚質を予測したあと, 事象 $u$ を経験して実際の感覚質を経験したとする. たとえば, 製品表面の触感を 感覚質とし，視覚で触感を予測した後，実際に触って触感を経験した場合である.

ここで，次に述べる三つの認知活動から得られる感覚質を仮定する，一つ目は，事象 $u$ のみによる感覚質であ り， $s_{u} \in X$ で表す．視覚による事前の予測なしに触覚のみによって経験した触感が対応寸る. 二つ目は, 事象 $v$ を手掛かりとした事象 $u$ による感覚質の予測であり, 主観確率分布 $\mathrm{P}(\mathrm{X})$ に従う確率変数 $S_{v} \in X$ で表す. 視覚によ って予想した触感に対応寸る. 三つ目は, 事象 $v$ にるる予測を伴った事象 $u$ にる感覚質であり, これを $s_{u v} \in X$ とする. 視覚により予測した後触覚で経験した触感に対応する.

これらの三つの感覚質の間には，三種類の差異がある．まず，我々が経験する期待と実際の不一致は，予測と 予測後の経験の差であるから，期待不一致 $\mathrm{d}_{u v}$ は式 (1) となる.

$$
\mathrm{d} s_{u v}=s_{u v}-\theta\left(S_{v}\right)
$$

ただし， $\theta\left(\mathrm{S}_{\mathrm{v}}\right)$ は $\mathrm{S}_{\mathrm{v}}$ の代表值である.つぎに，予測と予測を伴わない経験の差を予測誤差 $\Delta s_{u v}$ とすると式(2)と なる。

$$
\Delta s_{u v}=s_{u}-\theta\left(S_{v}\right)
$$


期待効果は，予測を伴わない経験と予測を伴う経験の差と考えられるため，式(3)となる.

$$
\varepsilon_{\mathrm{uv}}=\mathrm{s}_{\mathrm{uv}}-\mathrm{s}_{\mathrm{u}}
$$

これらの三つの関係は,

$$
\mathrm{ds}_{\mathrm{uv}}=\Delta \mathrm{s}_{\mathrm{uv}}+\varepsilon_{\mathrm{uv}}
$$

となる。したがって，期待効果が生じない場合，期待不一致は予測誤差と等価であるが，期待効果が生じると， 期待不一致に影響することが分かる．なお，期待不一致の絶対值を増加させる期待効果が対比，減少させる期待 効果が同化である.

\section{$2 \cdot 3$ 期待効果の強度と発生条件の定式化}

事象 $v$ を手掛かりとして予想した事象 $u$ による感覚質 $x$ の主観確率を $\operatorname{Pr}\left(S_{v}=x\right)$ とする. $\operatorname{Pr}\left(S_{v}=x\right)$ は, 感覚質 $x$ を事前にどの程度予測していたかを意味する．才なわち， $\operatorname{Pr}\left(S_{v}=x\right)$ が 1 に近い場合は予想通りであり，0 に近い 場合は予想外である，情報理論によると，発生した事象から獲得する情報量は，その事象の発生確率の対数に反 比例する(Shannon, et al., 1949). したがって，遷移後に感覚質 $x$ を経験したことによって獲得する情報量 $I_{x}$ は,

$$
I_{x}=-\log \left(\operatorname{Pr}\left(S_{v}=x\right)\right)
$$

となる．主観確率が低い事象を経験することにより多くの情報量を得た場合，感情の喚起度（arousal）が高ま り，刺激対象に対する注意が促される(Itti and Baldi, 2009). 予想外の新規な刺激に注意を向けることで，感覚入 力に対する利得を高めると考えた．そこで，獲得する情報量 $I_{x}$ と期待効果の強度 $\varepsilon_{u v}$ に正の関係があると仮説を 立てた（仮説 2 ).

一般に，我々の知覚は，知識や経験にもとづくトップダウン処理（予測）と，感覚入力によるボトムアップ処 理の統合からなる.トップダウン処理である予測の不確実性は, 知覚の統合において, これらの二つの処理の優 位性に影響する(Strange, et al., 2005). すなわち，予測の不確実性が高い場合はボトムアップ処理が優勢となり， 不確実性が低い場合はトップダウン処理が優勢となる．期待効果は，事前の予測が事後の経験に与える影響であ る. したがって, 予測の不確実性が低くトップダウン処理が優勢な場合において期待効果が発生すると考えた. 逆に，予測の不確実性が高ければ，ボトムアップ処理が優勢となり入力される感覚情報を素直に知覚するため期 待効果は発生しにくくなると考えた.

予測が不確実な場合, 主観確率分布は一様分布に近づく. 逆に, 不確実性が高いとは, ある值のみが高い確率 をとる確率分布を意味する.この様な確率分布の様相は, 確率分布の情報エントロピーを用いて定量的に示すこ とができる．すなわち，予測の不確実性は主観確率分布の情報エントロピーとして，

$$
H\left(S_{v}\right)=-\sum_{x \in X} \operatorname{Pr}\left(S_{v}=x\right) \log \operatorname{Pr}\left(S_{v}=x\right)
$$

と表すことができる，情報エントロピーは，事後に獲得しうる情報量の期待值を意味する．以上から，期待効果 の発生条件，およびその強度の仮説を式(7)により表すことができる.

$$
\varepsilon_{u v}= \begin{cases}f\left(I_{x}\right), & \left(H\left(S_{v}\right)>\theta_{\mathrm{H}}\right) \\ 0, & \left(H\left(S_{v}\right)<\theta_{\mathrm{H}}\right)\end{cases}
$$

ただし， $f(x)$ は正関数， $\theta_{\mathrm{H}}$ は情報エントロピーのしきい值をあらわす.

\section{3. 視覚による触覚の期待効果を用いた提案モデルの妥当性}

\section{$3 \cdot 1$ 実験の目的}

2 章で提案した期待効果の発生条件および強度に関するモデルの妥当性を確認するために，テクスチャ表面に 対する触覚上の粗さの視覚による期待効果に関する実験を行った．筆者らは既報(柳澤，高辻，2012)において， テクスチャの視覚情報が表在感覚に与える期待効果の存在を実験により確認している. しかし, 期待効果の発生 要因およびその強度の要因については未解明のままである. そこで, 提案モデルの仮説にもとづき, 視覚情報に よる予測がテクスチャの触覚に与える期待効果の発生条件とその強度を被験者実験により検証する. 
テクスチャの触覚（すなわち, 表在感覚）は, 粗さ, 温度, 硬さ, 乾湿などの次元から構成されるが, その中で も粗さは材質によらず共通した次元である(Okamoto, etal., 2012). また，粗さは，視覚情報を用いて予測可能な属 性である，そこで，本実験ではテクスチャ表面の粗さ感の知覚における視覚の期待効果を対象とした.

\section{$3 \cdot 2$ 評価サンプルおよび実験参加者}

評価サンプルは，既報と同様に樹脂製の梨地シボサンプル板を用いた．シボとは樹脂成形において金型の表面 にエッチングやサンドブラストを用いて凹凸をつけ成形面に転写した面である. 塗装などの二次処理を必要とせ ず意匠性，保守性等に優れているため，自動車の内装や電気製品の表面などの人が見て触る表面に用いられてい る. 目的に応じてシボの凹凸度合いを選択するため, 異なる表面粗さを有するサンプルプレートが提供されてい る. 本研究では，日本インダストリアルデザイナー協会（JIDA）が提供するサンプルプレートを用いた. 用い たサンプルは, HIPS 樹脂製の板であり表面に 10 段階の異なる粗さをもつ梨地加工を施したものである. 表面粗 さは最小で $\mathrm{Ra}=1.56 \mu \mathrm{m}$, 最大で Ra14.46 $\mu \mathrm{m}$ であり, その間において感覚上の粗さが等間隔になるように作成 されている. 表面粗さの小さい順に PS1 から PS10 と呼称する. ただし, PS7 と PS8 の間における触覚上の粗さ 感の差違が識別困難であったため PS8 を除外した. この 9 つの梨地シボサンプルに加え, シボ加工を施してい ない平滑面 FL を加えた 10 種を触覚用サンプルとして用いた.

実験参加者は，視覚および触覚に障害のない 20 代の大学生 31 名(男子 17 名, 女子 14 名)とした.

\section{$3 \cdot 3$ 実験方法}

本実験は，二つのフェーズから構成される．第一フェーズでは，テクスチャの視覚情報から予想される触覚上 の粗さの主観確率分布を取得した，取得した主観確率分布を用いて情報エントロピー，および触覚の経験から得 られる情報量を計算する，第二フェーズでは，図１に示すハーフミラーを用いて視覚情報と触覚情報の組合せを 合成呈示し, 視覚予測を伴う粗さ感と伴わない粗さ感とを比較評価させその差から期待効果の強度を評価した. 期待効果の強度と情報エントロピーおよび情報量との関係を分析することで, 提案モデルの妥当性を考察する. 以下に，各フェーズの詳細を説明する.

\section{フェーズ $1:$ 主観確率分布の取得}

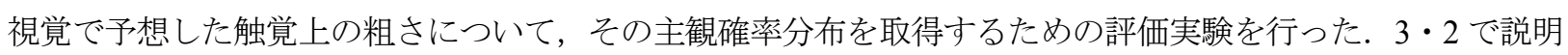
した 10 種の評価サンプルを 2 セット用意した。一方は視覚呈示用, 他方は触覚呈示用である. まず，視覚呈示 用のサンプルをランダムに 1 つ選択し, 実験参加者の前に呈示した. 次に暗幕で視覚情報を遮断した触覚呈示用 サンプルを触覚のみの条件で呈示し, 視覚呈示したサンプルから予想される触覚上の粗さとの一致性を評価させ た.この評価を，すべての触覚サンプルについて 2 回ずつ行った．触覚呈示用サンプルの呈示順序は，まず， FL, PS1, PS2,...,PS10 のように滑らかな方から呈示し, 次に, PS10, PS9, ...,PS2, FL のように粗い方から呈示し た. 以上の手続きを全ての視覚用サンプルについて実施した. 触覚呈示用サンプルごとに, 粗さ感が一致すると 回答した触覚サンプルそれぞれの頻度を集計した。この頻度分布を百分率として主観確率分布とした.

\section{フェーズ 2 : 期待効果の評価}

触覚上の粗さに対する視覚予測の期待効果 $\varepsilon_{u V}$ を抽出するための評価実験を行った. 視覚予測と触覚の不一致 を系統的に操作寸るために, ハーフミラーを用いて $2 つ$ つ評価サンプルの視覚と触覚を合成し呈示した. 図 1 に，八ーフミラーを用いた合成呈示装置の模式図を示す．合成呈示装置は，観察者が覗く空を有する立方体と箱 の中に 45 度に配置したハーフミラーから構成される. 八ーフミラーに対して線対称になる位置に, ハーフミラ 一の手前に視覚用サンプル, 奥に触覚用サンプルを置く. 視覚用サンプルがハーフミラーに 45 度に反射し, 奥 側に置いた触覚用サンプルの位置に重なって映る．このとき，視覚用サンプルと触覚用サンプルを照らす光源を 独立に調整し，手前を奥側よりも明るくすることで，観察者は視覚サンプルのみを見ることになる，つまり，観 察者は, あたかも視覚用サンプルを触るかのように, 触覚用サンプルを触ることが可能になる. 環境光を遮断し た条件下において，視覚サンプル側を 10001x，触覚サンプル側を約 1501x に調光したところ，ハーフミラーを介 した場合と介さない場合の間で，本実験で使用したサンプルの見えが一致することを目視で確認した. 
本実験では，視覚用のサンプルとして，3・2 で説明した FL およびPS1 から PS10までの 10 種を用いた。触 覚用のサンプルとしては，中程度の粗さを有する PS4 を選定した．視覚用サンプルおよび触覚用サンプルの全 通り組合せ 10 組を合成呈示し評価刺激とした.

評価方法は，基準刺激との比較によるマグニチュード推定法（以下，MS 法）を用いた. 基準刺激は，合成呈示 した触覚側のサンプルと同一の PS4 である．被験者は，まず，基準サンプルを触覚のみの条件で触らせた，その 後，ハーフミラーで合成呈示したサンプル 1 組について評価刺激を見てから触らせた。 そして，基準刺激の粗さ 感を 100 としたときの, 評価刺激の粗さを数值で回答させた. 評価刺激が基準刺激よりも粗いと感じた場合は 100 よりも大きい值，粗くないと感じた場合 100 よりも小さい值を回答した。基準刺激と評価刺激の触覚用サンプル は物理的に同じ粗さである.そのため，100よりも大きい（または小さい）值を回答した場合，その差分が期待 効果となる. この処理は，式（3）にもとづいている. つまり，基準刺激の評価が $s_{u}$, 評価刺激の評価が $s_{u v}$ にれ ぞれ対応する，以上の評価を，各被験者が全ての評価刺激について実施した．評価刺激の視覚用サンプルは，ラ ンダムな順序で呈示した.

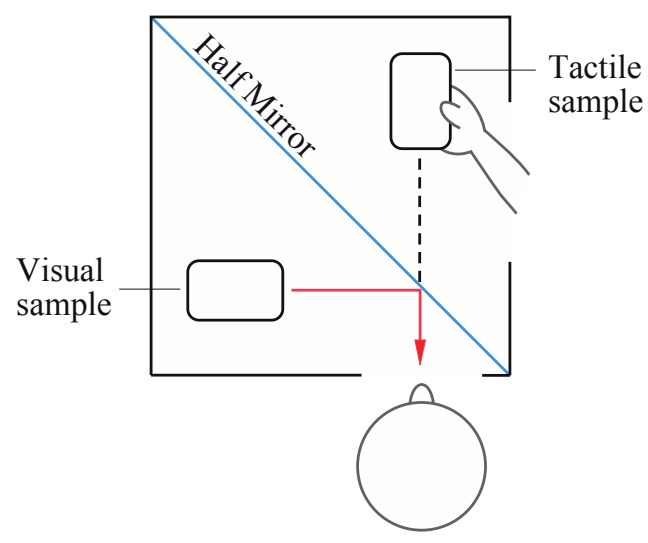

Fig. 1 Top view of evaluation apparatus that enables to synthesize visual and tactile information using a half mirror

\section{4. 実験結果と考察}

\section{$4 \cdot 1$ 情報エントロピーと期待効果の発生}

実験のフェーズ 1 において，実験参加者に視覚のみの条件で提示したサンプルから触覚上の粗さを予想させ， その粗さと一致するサンプルを 10 種の触覚用サンプルから複数回答を許して選択させた. 図 2 に, 視覚呈示した 各サンプルについて，10 種の触覚用サンプルごとに一致すると回答した頻度の百分率で表した分布を示す. 各折 れ線グラフは，それぞれ視覚のみの条件で提示した視覚用サンプルに対応し，粗さ感が一致すると回答した被験 者数の割合を触覚サンプルごとに示している.すなわち，図 2 は各視覚用サンプルから予測した触覚における粗 さ感における主観確率分布と対応する．表面粗さのスケールで両極の視覚用サンプル，すなわち表面粗さが最小 付近(FL, PS1), および最大付近（PS9,PS10）の分布形状が急である一方，中程度の表面粗さになるほど分布の形 状がなだらかな傾向がタられる. 図 2 の頻度率を百分率にして主観確率とし, 視覚サンプルごとの主観確率分布 から計算した情報エントロピーを図 3 に示した。図 3 より，両極の視覚用サンプルにおいて情報エントロピーが 低く, 中程度の表面粗さにおいて情報エントロピーが高いことが分かる．情報エントロピーは予測の不確実性を 意味する. すなわち，両極の視覚サンプルの方が，中程度の表面粗さを有する視覚サンプルよりも粗さ感に対す る視覚予測の不確実性が低いといえる，表面粗さの強弱がはっきりしたサンプルの方が，視覚によって触覚上の 粗さを特定しやすいためと考えられる. 


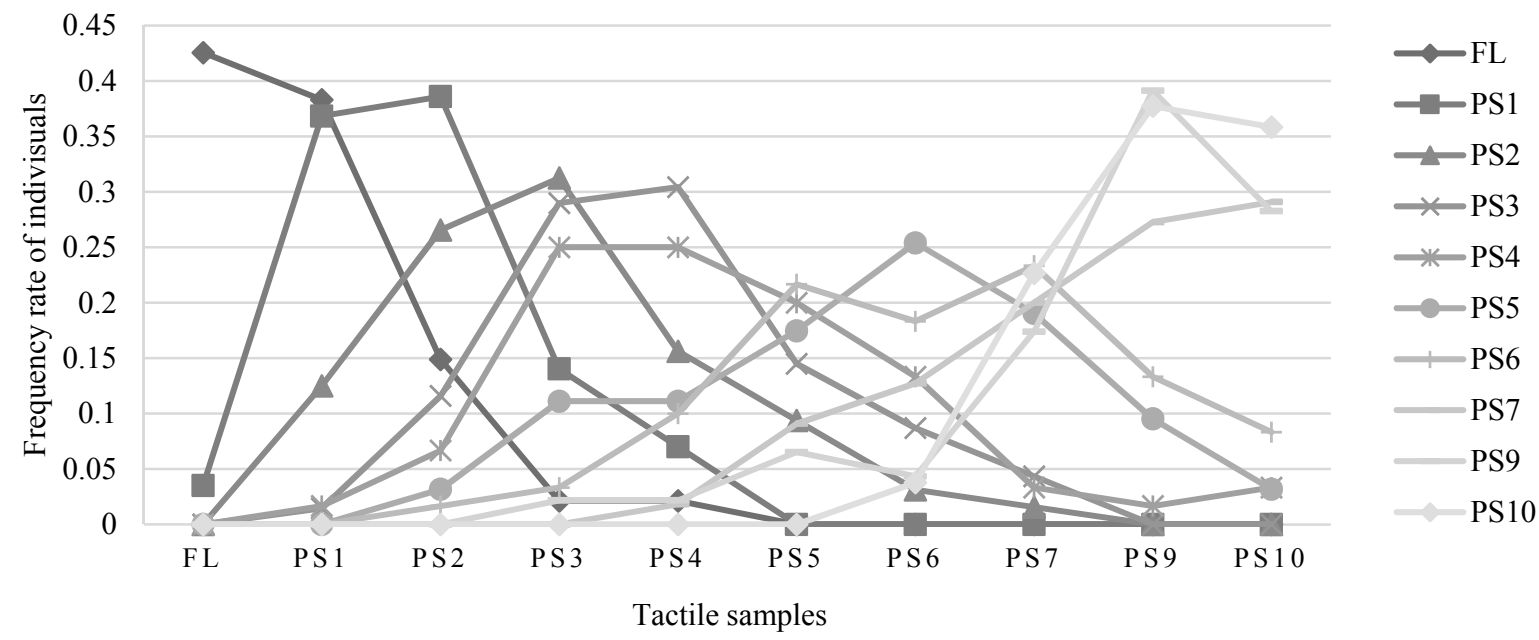

Fig. 2 Frequency rate distributions of participants who responded that visually expected roughness agreed with tactually experienced on for each tactile sample. Distribution shapes for obvious roughness such as FL and PS10 are sharp, whereas ones for moderate roughness such as PS5 are gentle.

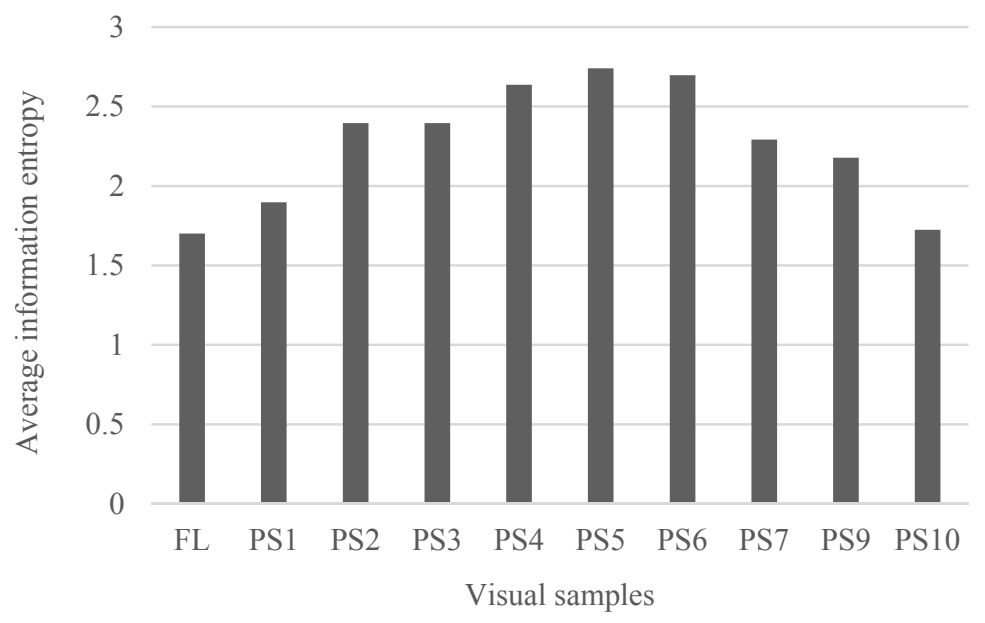

Fig. 3 Information entropy indicating uncertainty using each visual sample as expectation cue

仮説 1 では，視覚予測における主観確率分布の情報エントロピーが一定值以下，すなわち予測の不確実性が小 さい場合に期待効果が発生するとした。この仮説を確かめるために，実験のフェーズ 2 で評価した評価刺激（ハ ーフミラーにより合成呈示されたサンプルの粗さ感）の期待効果が発生した件数と情報エントロピーとの関係を 調べた.

図 4 に基準刺激と評価刺激の粗さ感が異なると回答した被験者数（すなわち，期待効果が発生した件数）と情 報エントロピーの関係を散布図で示す，散布図の各点は，八ーフミラーで合成した視覚サンプルにそれぞれ対応 している. 全ての視覚サンプルに対して，およそ半数以上の被験者において期待効果が発生していることがわか る. 図 4 から情報エントロピーが減少するとともに，期待効果の発生件数が増加している傾向がみられる.

図 5 に，合成呈示した視覚用サンプルのそれぞれについて，期待効果発生の有無の件数（被験者数）の割合を 示す. 触覚サンプルと同一の視覚サンプル（PS4）周辺における期待効果の発生件数は 50 65\%である. 一方, 表面粗さが最小の PS1 および平滑面（FL）においては期待効果の発生件数が 70〜 80\%であり，相対的に高い確 率で発生している．PS1 およびFL は図 3 において情報エントロピーが小さいことから，視覚による予測の不確 実性が小さい，このことから，相対的に高い割合で期待効果が発生したと考えられる. 


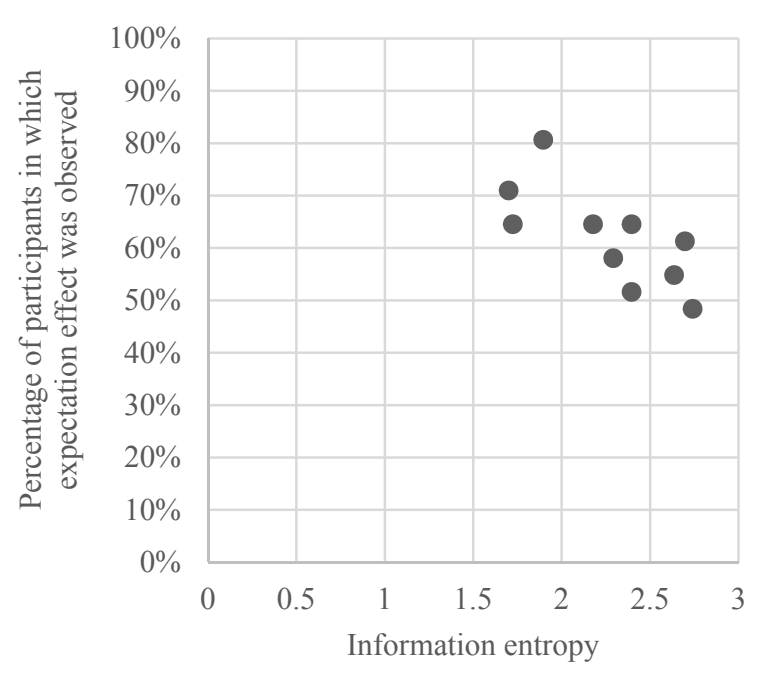

Fig. 4 Relation of occurrence of expectation effect and average information entropy. Information entropy tends to negatively correlate with occurrence frequency of expectation effect.

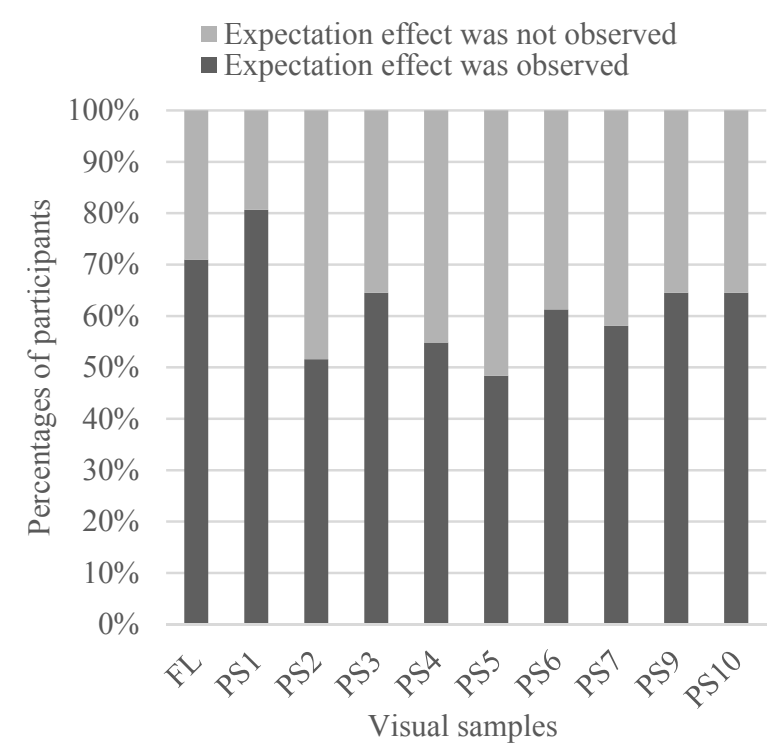

Fig. 5 Percentage of participants in which expectation effect was observed for each visual sample. For FL and PS1 involving low information entropy (i.e. certain prediction), expectation effect was observed in relatively high frequency.

\section{$4 \cdot 2$ 選択情報量と期待効果の度合い}

仮説 2 では，事後に得られる情報量が，期待効果の度合いに影響するとした．本実験では，実験のフェーズ 2 において，評価刺激を見てから触った際に評価者がえられる情報量が，期待効果に与える影響に対応する。そこ で，図 2 のPS4 における視覚用サンプルごとの回答頻度を，そのサンプルを見ることで粗さが PS4 と同等であ ると予想する際の主観確率とみなし，式(5)により触覚用サンプル（PS4）を触った後に取得する粗さに関する情 報量を計算した。図 6 に，各視覚用サンプルにおける情報量の計算值を示すたただし，視覚サンプルPS10にお いては，PS4 に対する主観確率が０であり分母がゼロとなって情報量が無限大であるためグラフには図示してい ない. 図6から，PS4 と表面粗さが近い視覚サンプルにおいては情報量が小さいく，PS4 と異なる粗さを有する 視覚サンプルにおいては情報量が大きい. つまり，視覚サンプルで予想した粗さ通りの場合よりも，予想と異な る粗さである場合に獲得する情報量が大きいことを表している.

図 7 に，基準刺激（触覚のみ条件での PS4）との評価值の差 $\mathrm{s}_{\mathrm{uv}}-\mathrm{s}_{\mathrm{u}}$ ， すなわち期待効果の度合いについて，值 が正の場合と負の場合のそれぞれを平均した值を示す。つまり，基準刺激よりも粗いと回答した評価值の平均 と，基準刺激よりも滑らかと回答した評価值の平均を，それぞれ 100 （基準刺激の評価值）から引いた值を示し ている. PS2，PS3，およびPS4 は，正負ともに期待効果の度合いが同程度である. 図 6 に示したように，これ ら 3 つの視覚サンプルにおける情報量は最も小さい. つまり，主観確率が大きく，予想通りの場合の期待効果の 度合いを示している，視覚と触覚が一致する PS4 と比べて，FL およびPS1 において，負の期待効果の度合いが 顕著である。これは，触覚サンプル PS4 よりも滑らかな FL および PS1 を視覚サンプルとして合成したときに， より滑らかに知覚される効果の度合いを表している。つまり，FL および PS1 においては視覚情報に同化する効 果が顕著であるといえる。一方, PS4 よりも粗い視覚サンプルにおいては，より粗く知覚される効果の度合いが 基準よりも高い. すなわち，触覚サンプルよりも粗い表面粗さを有する視覚サンプルを用いて粗さを予測させる と，触覚上でもより粗く知覚される同化効果であると言える.

以上から，本実験で使用したサンプルにおいては，一定の情報量を伴う視覚情報を合成することにより，同化 の度合いが強まる傾向が確認された。一方，同化と逆の期待効果である対比に関しては，情報量の違いによる度 合いの傾向が見られない. 対比は，同化よりも期待不一致が大きい場合に生じるとの傾向が知られている(Wilson, 
et al., 1989)(Geers and Lassiter, 1999).この原因として，本実験で選定した視覚サンプルの粗さに対する範囲が限定 的であったことが，対比が顕著に観察されなかったことが考えられる.

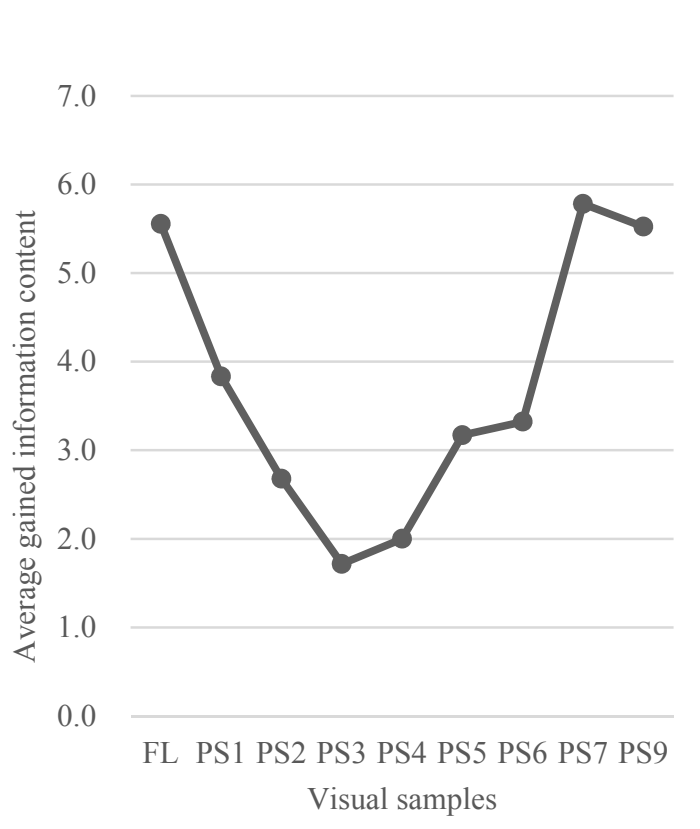

Fig. 6 Gained information content after experiencing PS4 as tactile stimulus for each visual sample as expectation cue. The information content for PS10 is infinite because its probability is zero.

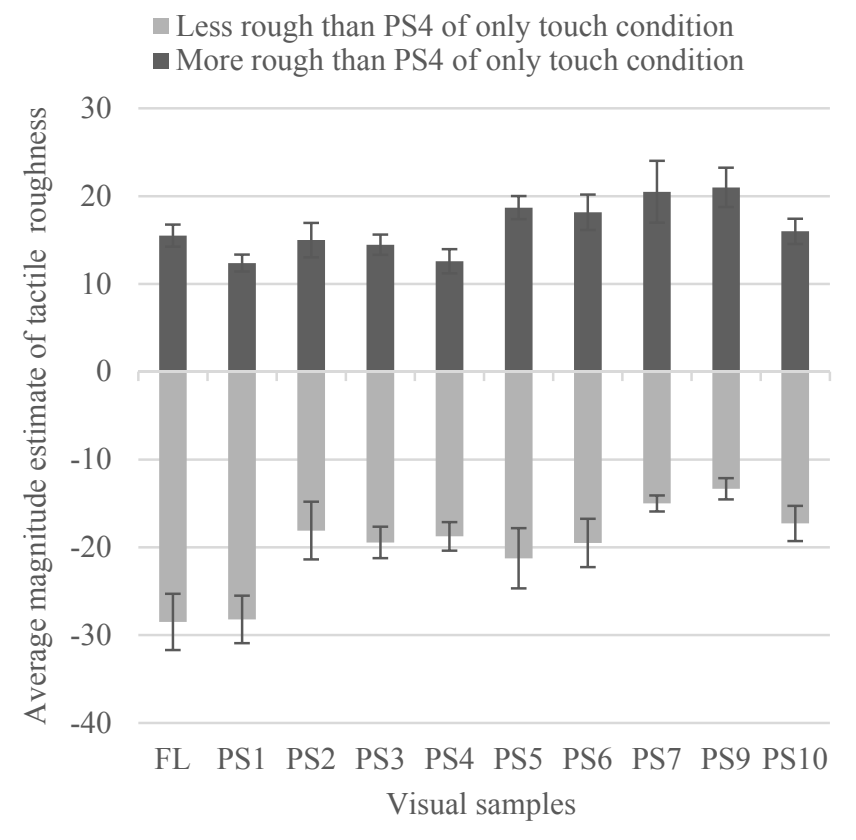

Fig. 7 Average difference in magnitude estimate of tactile roughness between PS4 with and without visual expectation for each visual sample used as expectation cue. Averages and standard errors for positive and negative scores are independently calculated. The error bars represent standard errors. Negative expectation effect was prominent for visual samples such as FL and PS1 in which participants gained high information content.

\section{5. 結 語}

本研究では，事前の期待が事後の経験に作用する期待効果について，その発生条件および度合いを説明するた めの数理モデルを提案した．期待効果の存在は，製品を使用する前の期待や予測が，感性評価に影響することを 意味する。したがって，期待効果は，顧客の感性にもとづく品質評価を考慮した設計において無視できない因子 である.

提案モデルでは，期待を主観確率分布として定量的にあらわし，分布から計算される情報エントロピーを期待 の不確実性の指標とした。そして，予測の不確実性が小さいとき（情報エントロピーが小さいとき）に，期待効 果が発生するとの仮説を立てた（仮説 1 ）。また，事後の経験から得られる情報量を主観確率分布から計算し， 情報量が期待効果の度合いに正に関係すると考えた（仮説 2 ）。テクスチャ表面の粗さ知覚に対する視覚予測の 期待効果を用いた被験者実験の結果から，情報エントロピーと獲得する情報量を定量化し，上記二つの仮説を支 持する傾向を確認した．感性品質に当てはめて考えると，不確実性の小さな（確信を伴った）顧客の期待に対し て，期待と大きく異なる品質を提供した場合に，期待効果が大きく作用することを示唆している.

不確実性と予想外の度合いを，それぞれ情報エントロピーと情報量として定式化することにより，期待効果の 発生条件と強度についての一般的な指標を提供しうる. 今後は，提案した仮説を多様な対象に適用し，その一般 性を検証する必要がある。

\section{謝 辞}


本研究は科研費（No. 23760127）の支援を受けて実施した. 東京大学大学院工学系研究科の村上存教授, 中川 聰特任教授，上田一貴特任講師には貴重な御助言を頂いた。 心より御礼申し上げます.

\section{文献}

Buckingham, G., Ranger, N. S. and Goodale, M. A., The material-weight illusion induced by expectations alone, Attention Perception \& Psychophysics, Vol.73, No.1(2011), pp. 36-41.

Deliza, R. and MacFie, H. J. H., The generation of sensory expectation by external cues and its effect on sensory perception and hedonic ratings A review, Journal of Sensory Studies, Vol. 11, No. 2(1996), pp. 103-128.

Demir, E., Desmet, P. M. A. and Hekkert, P., Appraisal patterns of emotions in human-product interaction, International Journal of Design, Vol. 3, No. 2(2009), pp. 45-51.

Flanagan, J. R. and Beltzner, M. A., Independence of perceptual and sensorimotor predictions in the size-weight illusion, Nature Neuroscience, Vol. 3, No. 7(2000), pp. 737-741.

Geers, A. L. and Lassiter, G. D., Affective expectations and information gain Evidence for assimilation and contrast effects in affective experience, Journal of Experimental Social Psychology, Vol. 35, No. 4(1999), pp. 394-413.

Itti, L. and Baldi, P., Bayesian surprise attracts human attention, Vision Research, Vol. 49, No. 10(2009), pp. 1295-1306.

Kawato, M., Trajectory formation in arm movements Minimization principles and procedures, In Zelaznik HN, ed. Advances in Motor Learning and Control(1996), pp.225-259, Human Kinetics Publ. Chanpaign Illinois.

Körding, K. P., and Wolpert, D. M.. Bayesian integration in sensorimotor learning, Nature, Vol. 427, No. 6971 (2004), pp. 244247.

Krippendorff, K., The semantic turn A new foundation for design(2005), CRC Press.

Ludden, G. D. S., Schifferstein, H. N. J. and Hekkert, P., Beyond surprise A longitudinal study on the experience of visualtactual incongruities in products, International Journal of Design, Vol. 6, No. 1(2012), pp. 1-10.

Mori, N., Rough set approach to product design solution for the purposed KANSEI, Bulletin of Japanese Society for the Science of Design, Vol. 48, No. 6(2002), pp. 85-94.

Murakami, T., Nakagawa, S. and Yanagisawa, H., Proposal of Expectology as design methodology, Proceedings of the 18th International Conference on Engineering Design, Impacting Society through Engineering Design, Vol. 7 Human Behavior in Design (2011), pp.224-233.

Okamoto, S., Nagano, H. and Yamada, Y., Psychophysical dimensions of tactile perception of textures, IEEE Transactions on Haptics, Vol. 6, No.1(2012), pp. 81-93.

Oliver, R. L., A cognitive model of the antecedents and consequences of satisfaction decisions, Journal of Marketing Research, Vol. 17, No. 3 (1980), pp. 460-469.

Oliver, R. L., Effect of expectation and disconfirmation on postexposure product evaluations An alternative interpretation, Journal of Applied Psychology, Vol. 62, No. 4(1977), pp. 480-486.

Schifferstein, H. N. J.. Effects of product beliefs on product perception and liking, In Food, People and Society (2001), pp. 73 96 , Springer.

Schultz, W., Dayan, P. and Montague, P. R., A neural substrate of prediction and reward, Science, Vol. 275, No. 5306 (1997), p. 1593.

Schütte, S. T. W., Eklund, J., Axelsson, J. R. C. and Nagamachi, M., Concepts, methods and tools in Kansei engineering, Theoretical Issues in Ergonomics Science, Vol. 5, No. 3 (2004), pp. 214-231.

Shannon, C., Weaver, W., Blahut, R. and Hajek, B., The mathematical theory of communication, The Bell System Technical Journal, Vol. 27(1949), pp. 623-656.

Strange, B. A., Duggins A., Penny, W., Dolan, R. J. and Friston, K. J., Information theory, novelty and hippocampal responses, Neural Networks, Vol. 18, No. 3(2005), pp. 225-230.

Wilson, T. D., Lisle, D. J., Kraft, D. and Wetzel, C. G., Preferences as expectation-driven inferences Effects of affective expectations on affective experience, Journal of Personality and Social Psychology, Vol. 56, No. 4(1989), p. 519.

Yanagisawa, H. (Fukuda, S. ed.), Kansei quality in product design, In Emotional Engineering Service Development (2010), pp. 289-310, Springer.

柳澤秀吉, 勇木徳仁, 物体の表面属性に対する視覚的感性が持ち上げ時の体性感覚に与える影響（感覚モダリテ 1の遷移における予測感性），日本機械学会論文集 C 編, Vol.78, No.789(2012), pp. 609-620.

柳澤秀吉，高辻賢司，視覚による事前予測の影響を考慮したテクスチャの感性評価手法，日本機械学会論文集 C 
編, Vol. 78, No. 796 (2012), pp. 2-13.

\section{References}

Buckingham, G., Ranger, N. S. and Goodale, M. A., The material-weight illusion induced by expectations alone, Attention Perception \& Psychophysics, Vol.73, No.1(2011), pp. 36-41.

Deliza, R. and MacFie, H. J. H., The generation of sensory expectation by external cues and its effect on sensory perception and hedonic ratings A review, Journal of Sensory Studies, Vol. 11, No. 2(1996), pp. 103-128.

Demir, E., Desmet, P. M. A. and Hekkert, P., Appraisal patterns of emotions in human-product interaction, International Journal of Design, Vol. 3, No. 2(2009), pp. 45-51.

Flanagan, J. R. and Beltzner, M. A., Independence of perceptual and sensorimotor predictions in the size-weight illusion, Nature Neuroscience, Vol. 3, No. 7(2000), pp. 737-741.

Geers, A. L. and Lassiter, G. D., Affective expectations and information gain Evidence for assimilation and contrast effects in affective experience, Journal of Experimental Social Psychology, Vol. 35, No. 4(1999), pp. 394-413.

Itti, L. and Baldi, P., Bayesian surprise attracts human attention, Vision Research, Vol. 49, No. 10(2009), pp. $1295-1306$.

Kawato, M., Trajectory formation in arm movements Minimization principles and procedures, In Zelaznik HN, ed. Advances in Motor Learning and Control(1996), pp.225-259, Human Kinetics Publ. Chanpaign Illinois.

Körding, K. P., and Wolpert, D. M.. Bayesian integration in sensorimotor learning, Nature, Vol. 427, No. 6971 (2004), pp. $244-$ 247.

Krippendorff, K., The semantic turn A new foundation for design(2005), CRC Press.

Ludden, G. D. S., Schifferstein, H. N. J. and Hekkert, P., Beyond surprise A longitudinal study on the experience of visualtactual incongruities in products, International Journal of Design, Vol. 6, No. 1(2012), pp. 1-10.

Mori, N., Rough set approach to product design solution for the purposed KANSEI, Bulletin of Japanese Society for the Science of Design, Vol. 48, No. 6(2002), pp. 85-94.

Murakami, T., Nakagawa, S. and Yanagisawa, H., Proposal of Expectology as design methodology, Proceedings of the 18th International Conference on Engineering Design, Impacting Society through Engineering Design, Vol. 7 Human Behavior in Design (2011), pp.224-233.

Okamoto, S., Nagano, H. and Yamada, Y., Psychophysical dimensions of tactile perception of textures, IEEE Transactions on Haptics, Vol. 6, No.1(2012), pp. 81-93.

Oliver, R. L., A cognitive model of the antecedents and consequences of satisfaction decisions, Journal of Marketing Research, Vol. 17, No. 3 (1980), pp. 460-469.

Oliver, R. L., Effect of expectation and disconfirmation on postexposure product evaluations An alternative interpretation, Journal of Applied Psychology, Vol. 62, No. 4(1977), pp. 480-486.

Schifferstein, H. N. J.. Effects of product beliefs on product perception and liking, In Food, People and Society (2001), pp. 7396, Springer.

Schultz, W., Dayan, P. and Montague, P. R., A neural substrate of prediction and reward, Science, Vol. 275, No. 5306 (1997), p. 1593.

Schütte, S. T. W., Eklund, J., Axelsson, J. R. C. and Nagamachi, M., Concepts, methods and tools in Kansei engineering, Theoretical Issues in Ergonomics Science, Vol. 5, No. 3 (2004), pp. 214-231.

Shannon, C., Weaver, W., Blahut, R. and Hajek, B., The mathematical theory of communication, The Bell System Technical Journal, Vol. 27(1949), pp. 623-656.

Strange, B. A., Duggins A., Penny, W., Dolan, R. J. and Friston, K. J., Information theory, novelty and hippocampal responses, Neural Networks, Vol. 18, No. 3(2005), pp. 225-230.

Wilson, T. D., Lisle, D. J., Kraft, D. and Wetzel, C. G., Preferences as expectation-driven inferences Effects of affective expectations on affective experience, Journal of Personality and Social Psychology, Vol. 56, No. 4(1989), p. 519.

Yanagisawa, H. (Fukuda, S. ed.), Kansei quality in product design, In Emotional Engineering Service Development (2010), pp. 289-310, Springer.

Yanagisawa, H. and Yuki, N., Effect of visual kansei of surface characteristics on somatosensory perception while lifting an object (Sensory prediction in transition of sensory modalities), Transactions of the Japan Society of Mechanical Engineers, Series C, Vol.78, No.789(2012), pp. 609-620 (in Japanese).

Yanagisawa, H. and Takatsuji, K., A Kansei evaluation method for surface texture considering with prior visual expectation, Transactions of the Japan Society of Mechanical Engineers, Series C, Vol. 78, No. 796 (2012), pp. 2-13 (in Japanese). 